\title{
Erratum to: Effect of water table drawdown on peatland nutrient dynamics: implications for climate change
}

\author{
M. L. Macrae • K. J. Devito • M. Strack • \\ J. M. Waddington
}

Published online: 4 September 2012

(C) Springer Science+Business Media B.V. 2012

\section{Erratum to: Biogeochemistry \\ DOI 10.1007/s10533-012-9730-3}

Due to a formatting error, the units in the figures were erroneously reported in $\mathrm{mg} \mathrm{g}^{-1}$. Units in Figs. 1-5 are in $\mu \mathrm{g} \mathrm{g}^{-1}$.

The online version of the original article can be found under doi:10.1007/s10533-012-9730-3.

M. L. Macrae $(\varangle)$

Department of Geography and Environmental

Management, University of Waterloo, Waterloo,

ON N2L 3G1, Canada

e-mail:mmacrae@uwaterloo.ca

\section{K. J. Devito}

Department of Biological Sciences, University of Alberta,

Edmonton, AB, Canada

M. Strack

Department of Geography, University of Calgary,

Calgary, AB, Canada

J. M. Waddington

McMaster Centre for Climate Change and School

of Geography and Earth Sciences, McMaster University,

Hamilton, ON, Canada 